\title{
AN ASSESSMENT OF THE PRIESTLY EMOLUMENT IN NUMBERS 18:8-32 ${ }^{1}$
}

\author{
Miracle Ajah \\ Old \& New Testament \\ Stellenbosch University
}

\begin{abstract}
This article seeks to examine how a theological reflection on the priestly emolument in Numbers 18:8-32 would enhance a better interpretation of stewardship amongst believing communities in Africa. Dependency syndrome amongst most African churches, especially those established by Europeans has robbed them of the prestige of adopting a selfsupporting/propagating programme. The thesis of this paper maintains that a good synchronization of the tradition-historical exegetical method proposed by Gnuse will facilitate a good interpretation of the priestly emoluments in Numbers 18 and their subsequent application to the church in Africa today. Comparable texts from the Ancient Near East that may have influenced Numbers 18 were surveyed; the possible oral prehistory of Numbers 18 was scrutinized; the connection of Numbers 18 to other priestly traditions was examined; and the use or interpretation of the pericope by the wider biblical tradition concluded the study. The practice of tithes in Numbers 18 was rooted in the theological understanding that the LORD was the owner of the land and the Israelites were to tithe all the wealth of the land as a means of submitting to that sovereign ownership. This same understanding will motivate a strong stewardship and independence amongst churches in Africa.
\end{abstract}

Key Words: Tithes, Priestly emolument, Numbers 18, Pentateuch

\section{Introduction}

The Book of Numbers centres on the problems and possibilities of shaping a community identity in tune with God's intentions for the creation, or for the church. It is a narrative spanning forty years of Israel's journey from Sinai to Moab, the threshold of the Promised Land. Levine (1993:48) reports that in its textual makeup, Numbers is the most diverse of all the Torah books. It includes historical narratives, collections of early Hebrew poetry, and extensive legal and ritual texts. In addition to its generic diversity, Numbers also exhibits a complex literary history. As a book of the Torah, it is held together in an intricate manner: a collection of relatively early Hebrew poetry and a limited body of collected historiography were greatly expanded by priestly writers, who radically recast the depictions of the wilderness period conveyed in them.

Although a complex literary work, the thesis of this paper maintains that a good synchronization of the tradition-historical exegetical method proposed by Gnuse will facilitate a good interpretation of the priestly emoluments in Numbers 18 and their subsequent application to the church in Africa today.

Paper presented at the Old Testament Society of South Africa conference, Stellenbosch University, 22-26 June 2009. 
It was observed that most churches in Africa cannot fund their programmes except if they receive assistance from Europe or America. This dependency syndrome has robbed most African churches, especially those established by white missionaries of the prestige of adopting a self-supporting and a self-propagating programme. The churches in Africa were bedevilled with a myriad of problems in the 20th century, which included: the migration of African Pastors/church workers to America or Europe in search of greener pastures, usually under the guise of pursuing further education in order to help their fatherland (many did not come back); inability to attend world conferences and capacity building programs abroad unless through sponsorship from the West; very poor living conditions of church workers and inability to fund building projects of the Church; slow pace of expansion in mission and church-planting efforts; proliferation of mushroom churches for material interests; a growth of Tent-Making/Part-time Ministries; and inability to fund Bible translation projects and the review/production of Hymn Books and liturgies that will reflect the African experience.

For our study of Numbers 18:8-32, we have redacted the steps in the method suggested by Gnuse $^{2}$ (1999:584-587) as follows: (1) Ancient Near Eastern parallels to Numbers 18. The study will consider comparable texts from the Ancient Near East that may have influenced the biblical authors in the written formation of the text. (2) The possible oral pre-history of Numbers 18 will be scrutinized to reveal possible developmental stages in their form, message and social setting. (3) The connection of Numbers 18 to the priestly tradition in the book of Numbers and Pentateuch will be examined. (4) The use or interpretation of the pericope by the wider biblical tradition will conclude the study.

So, this study reveals that the believing community in Numbers 18 was both independent and self-supporting. The practice of tithes in Numbers 18 was rooted in the theological understanding that the LORD was the owner of the land and the Israelites were to tithe all the wealth of the land as a means of submitting to that sovereign ownership, and as a provision for sanctuary personnel. It contends that this same understanding will motivate a self supporting effort amongst churches in Africa and extricate them from the dependency syndrome.

\section{A Preview of Numbers 18:8-32}

(a) Verses 8-10 gave a general introduction to the list of entitlements due to the priests, which were contributed by the Israelites. Also the most sacred gifts for the priests were enumerated.

(b) Verses 11-19. These verses enumerated the additional grants to the priests, which were

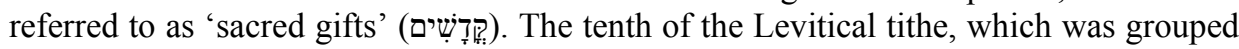
in this category, was listed separately in verses 25-32 for obvious reasons. These additional grants to the priests bore the lesser grade of sanctity, which entitled them to be eaten not just by the priests but also by members of their household who were in a state of ritual purity. The consumption was not restricted to the Tabernacle courtyard as

\footnotetext{
R Gnuse in his article: "Tradition History" in Dictionary of Biblical Interpretation (DBI 2), ( ed.) JH Hayes, Nashville: Abingdon, c1999. pp. 583-588, presented five helpful steps in the tradition-historical method of exegesis, which we adapted to four, namely: (1) Examination of comparable texts from the Ancient Near East that may have influenced the biblical authors in the oral or written formation of the biblical texts; (2) The possible oral pre-history of the biblical text being studied; (3) Envisioning how the biblical text might have grown into its present literary context; (4) A reflection on how the great cycle of narratives was connected to an even larger segment of literature; and (5)The use or interpretation of the genre by later biblical tradition.
} 
the most sacred gifts. The sacred gifts have the technical meaning of sacred food allowable to the priestly household as opposed to the most sacred food, which may be eaten only by the male priests.

(c) Verses 20-24. This section outlined the main entitlements of the Levites, as distinct from those of the priesthood. The Levites were to receive a tithe of all the annual produce of the fields, orchards, and vineyards, to be remitted to them by all Israelites. The tithe is portrayed here as a right and not as a privilege; as a right because it is morally and legally binding that a labourer deserves his/her wages; and not as a privilege because they duly merited it by their labour.

(d) Verses 25-32. The Levites who received the tithes were expected to give a tenth of the tithes to the priests. Apparently, the priests were exempted from tithing in Numbers. The writer of Hebrews 7:4-10 gives the impression that no one was exempted. It is not clear from Numbers how the priests, who received the tithe of tithes, could have paid tithes as inferred by Hebrews. So, verses 25-32 concentrated on the tithe of tithes for the priests. The Levites were cautioned against tampering with the tithe of tithes. How they managed the tithes determined what happened to them.

\section{Ancient Near Eastern Parallels to Numbers 18}

Similar to most of Israel's institutions, tithing in the Old Testament had some antecedents, and we must try to see what those antecedents or models might have been and where they may be found. This search cannot be made without an attempt to achieve some initial but accurate understanding of the nature of early Israelite society itself, for if we do not have this, we run the risk of drawing false parallels in our quest for the antecedents. The culture of Israel before the monarchy was not an urban culture. The practice of tithing in Numbers 18 did not depict exactly the practice in other ancient Near Eastern societies. The religious institutions of Egypt, Ugarit, Assyria and Babylonia are known to us through documents which already reflect organized urban civilizations whose complex priesthoods and cultic groups are far removed from the society of the semi-nomadic, then semi-sedentary, Israelites before the days of the monarchy.

Our duty in this section is to examine whether or not some ancient near eastern texts cited are similar to Numbers 18; and to determine to what extent they were antecedents to the concept and practice of tithing in the Old Testament, or at least, how they can assist in interpreting it. The selected texts are of four different forms, namely: (1) Royal texts, (2) Legal texts, (3) Religious texts, and (4) Economic texts.

\section{Royal Texts}

In our survey of Ancient Egypt (2850-1150BCE), we saw how the king of Egypt provided for the Temples and their personnel. Besides giving the temples their means of production, he appointed a structured priesthood with the chief priest at the head. McReady (1988:961) reports that a chief priest heading a priestly hierarchy was a fairly common phenomenon in the Ancient Near Eastern world. The prominence of the house of Aaron with priests in place of the entire tribe of Levi as projected in the book of Numbers, especially in chapter 18 in the allotment of priestly emolument, gives one the impression of the existence of a familiar tradition at that point in time. Thus, the stereotypic genre may have been well communicated to their audience; an exception perhaps was the rebellion motifs recorded in Numbers 16-17.

Moreover, a text portrayed the king of Egypt issuing decrees for the collection of tithes for the temple of Kahnum as a sign of gratitude to the deity who had promised him an end to the famine in the land. Some scholars believe that this text was based on a genuine Old 
Kingdom decree from the time of King Djoser of the third dynasty (Lichtheim 2002:130). It reads:

I awoke with speeding heart. Freed of fatigue I made this decree on behalf of my father Khnum. A royal offering to Khnum, lord of the cataract region and chief of Nubia:

In return for what you have done for me, I offer you Manu as western border, Bakhu as eastern border...

All fishermen, all hunters, who catch fish and trap birds and all kinds of game, and all who trap lions in the desert - I exact from them one-tenth of the take of all of these, and all the young animals born of the females in these miles [in their totality].

One shall give the branded animals for all burnt offerings and daily sacrifices; and one shall give one-tenth of gold, ivory, ebony, carob wood and ochre...

...firewood, the things that every man who works with them shall give as dues, namely one-tenth of all these. And there shall be given one-tenth of the precious stones and quarrying stones that are brought from the mountain side, being the stones of the east (Cos III 2002:133).

The message formula of this royal text, which includes the law giver, the motivation, the payer, and goods subject to tithe, share some resemblance with the tithe speech of Numbers 18. The payment of tithe was a command, and not a request. In Numbers, it was not just the human king who decreed it but the $\operatorname{LORD}(18: 1,8,21,25)$. The payment of tithe was an expression of gratitude. As in Ancient Egypt, the Israelites were to tithe as an expression of thanks to the LORD for possessing the land (vv 20, 24).

\section{Legal Texts}

A legal text found in Ugarit (ca. $14^{\text {th }}$ to $13^{\text {th }}$ Centuries BCE) is a contrast to what is found in Numbers 18. The king of Ugarit was the sole recipient of the tithes, which he distributed to many of his officials, among whom were the priests or temple personnel. Tithes were not exclusively for the temple personnel as it is found in Numbers. Let us do a comparison of the Ugarit text with Numbers:

\section{a) Ugarit}

From the present day on, Ammistamru ${ }^{3}$, son of Niqmepa, king of Ugarit has given to Yasiranu, son of Husanu, the village (alu) E[--]ish with everything it has forever, (also) to his sons and grandsons. Its grain, its beer (sikaru) of its (the village's) tithe, (ma'asharu) and the sheep - the pasturing tax (ma-aq-qa-du) shall be for Yasiranu. The silver of the gifts and the silver of the bridegroom's friend and service boys (su-sa-pi-in-nu-ti) shall be for Yasiranu (PRU III 16.153; COS III 2002:258; Fisher 1975:95).

\section{b) Numbers}

8 And the LORD spoke to Aaron, See! I have given to you the charge of my contributions of all the sacred gifts of the sons of Israel; I have given them to you and your sons as a portion, by a decree forever.

21 See! I have given to the sons of Levi every tithe in Israel for an inheritance in return for their service, which they are serving, the service of the tent of meeting (Num 18:8, 21).

3 Ammistamru II reigned ca. 1260-1225 BCE (COS III 2002:258). 
From the above texts we can observe the following contrasts in the concept and practice of tithing in Ugarit and Numbers. (This comparison is meant to be representative and not exhaustive):

\section{(a) Ugarit}

1. In Ugarit, the tithe was a royal tax which the king exacted for himself and for the benefit of his officials.

2. There was no theological motivation for the tithe at Ugarit.

3. The communities of different villages were treated as blocs in the payment of tithe.

\section{The villages existed for the king's benefit.}

\section{(b)Numbers 18}

1. In Numbers, it was reserved for the temple personnel.

2. The Israelites were to tithe as obedience to the words of the LORD to Aaron/Moses (see vv 8, 25).

3. Individuals were held responsible in this pericope ( $\mathrm{v} 26)$.

4. The people owe their possession of the land to the LORD.

\section{Religious Texts}

A religious text from Ugarit (KTU 1.119:26-35//RS 24.266), which falls within the sacrificial liturgy and psalmody of the Ugaritic, presented the tithe in the list of sacrificial items offered to Baal to repel an enemy attack (see Olmo Lete 1999:304,305). The favour of the deity is invoked to defend the land. The tradition of using a gift or sacrifice to appease the deity or invoke the blessing was a common feature in the Ancient Near East. A few Old Testament prophetic texts from the $8^{\text {th }}$ Century BCE will help us illustrate this point:

Come to Bethel and transgress; to Gilgal and multiply transgression; bring your sacrifices every morning, your tithes (ma'aser) every three days;

Bring a thank-offering of unleavened bread, and proclaim freewill offerings (...), publish them; for so you love to do, O people of Israel, says the Lord God! (Amos 4:4, 5).

For I desire steadfast love and not sacrifice, the knowledge of God rather than burnt offerings (Hosea 6:6).

The audience at Amos 4:4 might have been living under a traditional illusion that their gifts and sacrifices could buy them favour before the LORD, which Amos challenged; and it is also possible that the above notion must have been reasonably accessible to the author of and the audience that received Numbers 18 in written form. Numbers 18 was to serve as an antithesis to Numbers 16-17, the various accounts of rebellion which attracted the LORD'S judgement. So obedience to the LORD as demanded by Numbers 18 was a sure guarantee for enjoying God's blessings, physically represented by the Promised Land. Absolute obedience to the LORD'S command was intended, and not a mere exhibition of a ritual. 


\section{Economic Texts}

Ward (1992:370-371) highlighted the economic functions of the temple in Old Kingdom Egypt. Their economic system was based on a local subsistence economy in which the necessities of life were produced in all sectors of society without particular concern for open marketplace. The temples were involved at all levels, and the temples produced the food, clothing and other necessities required by their personnel. Royal grants and private donations (which included the compulsory tithes on all expeditions) expanded temple property; this meant a commensurate increase in agricultural labourers, craftsmen and other workmen needed to maintain the temple's subsistence economy. The real growth of temple wealth came during the Empire period - ca 1540-1100 BCE (Ward 1992:371). As it were, the temples were not institutionally or economically independent of the state. State employees such as the royal workmen in the Valley of the King, were paid in kind by the state out of temple treasuries. Thus, the temple acted as a kind of banking system for the state and paymaster for government workers.

Meanwhile, a list of goods subject to tithing was cited in an economic text from Ugarit (PRU III 10.044; COS III 2002:201). They were tithes and taxes from the villages. Among the items listed were tithes taken from a wide range of property, produce or even currency. They included grain, oil and wine, the staple food of the Levantine economy. Agricultural yield was particularly emphasized with explicit reference to its tithes. Throughout the Ancient Near East all kinds of objects have been found designated as subject to the tithe: wool, cloth, wood, weapons, gold, silver, donkeys, etc. (Carpenter 1988:861).

Numbers 18 clearly reflects a fusion of the state and the sanctuary. There is no distinction between the secular and the sacred, as far as the government of the people was concerned. The tithe system in Numbers 18 was more or less a tax system from the state for the upkeep of the religious institution. Although the goods subject to tithes in Numbers were similar to those found in other Ancient Near Eastern cultures (cf. Num 18:12; Deut 14:23; see also Milgrom 2004:3, 4), the pericope does not depict an actual practice at the time but an anticipation thereof. Some of these gifts could not possibly be brought until Israel had become a settled agricultural community. These rules were to be a lasting ordinance for the generations to come (v 23).

\section{The Possible Oral Pre-History of Numbers 18}

Our second area of consideration is the possible oral pre-history of Numbers 18 under survey. We will discuss: (1) the earlier traditional form. What was the original extent of the oral form in contrast to the present written form? (2) Social setting. Who spoke the original oral form, and to whom was the oral form addressed? (3) Earlier message. What was the earlier message, and how might it be different from the messages communicated in later oral and written stages?

\section{Earlier Traditional Form}

There are some Old Testament texts that suggest the possible existence of oral pre-history for the concept and practice of tithing. The present genre under survey was a possible legislative emendation or restructuring of an oral form. Our allusion comes from the various texts that mention tithing in connection with either central or local sanctuaries. Let us examine some of the texts: Salem (Gen 14:18-20); Bethel (Gen 28:20-22); and Gilgal and Bethel (Amos 4:4, 5). 
It is clear from the above references that tithes were received at the featured sanctuaries. But it is not clear what must have informed the actions of Abram or Jacob in the payment of tithes. Were they responding to any given law or were they acting in accordance with the prevalent tradition of the period? Either way, there must have been an oral pre-history of their actions. Moreover, the sarcastic way the prophet Amos asked for a tithe every three days, instead of, maybe annually, or every three years, was a direct attack on a discordant tradition of his period. According to Verhoef (1974:120), Amos' comment "has an interesting point of reference in an old tradition: Bethel was the place where Jacob promised to give a tenth of all his possessions to the LORD." On the same hand, in arguing for the existence of an earlier tradition, Milgrom (1976:61), presented that the patriarchal narratives of Abraham at Salem (Gen 14:20) and Jacob at Bethel (Gen 28:20) were not accidental because they were the sites of the main sanctuaries of the kingdoms of Judah and Israel respectively. The purpose of the narratives may be etiological: to prove that the rights of these two sanctuaries are hallowed by tradition, traceable to the patriarchs themselves. Jagersma (1981:127) reports that the oldest traditions in the Old Testament strongly suggest a custom of taking tithes to a local sanctuary which in many cases appears to be a royal sanctuary. The Numbers' legislation for tithing must have been in full view of some of these existing traditions. The priests and the Levites who were the personnel of the sanctuaries became the recipient of tithes in Numbers.

Knierim and Coats (2005:215-220), in their form-critical analysis of Numbers 17:27$18: 32$, observe that the unit is a collection of five speeches, each with its own genre identity. They are: (a) Lamentation cries (17:27-28); (b) Ordination speech for priesthood (18:1-7); Wages speech for Aaron's priestly service (18:8-19); (c) Inheritance speech establishing wages for Levi (18:20-24); and (d) Ordinance speech, which lays legislative claim to a tithe from Levi's wages (18:25-32). It is believed that the collection of ordinances in this unit stands at the end of a long history of tradition; and that the ordinances have been appropriated out of earlier contexts, altered only in order to bend them to the unifying theme of the pericope, and placed in the appropriate slot (Knierim \& Coats 2005:219).

\section{Social Setting}

As we can see from the above discussion, the background tradition history of tithing centres on the activity of the sanctuary and the priesthood. The final concern is to establish the priesthood's authority, particularly Aaron's authority over the process of worship. The attack by Korah and others against Aaron and his sons concerning their priestly duties prompts the reaffirmation of Aaron's role as high priest and the laws for supporting the priests. The many Israelite rebellions had repeatedly prompted God's judgment of death and plagues so that the community was constantly threatened with the impurity and pollution of contact with dead bodies, which rendered a person unclean (Num 5:2). The distinctive ministry of Moses and Aaron had been ruthlessly challenged. The two men were in need of the LORD'S encouragement, and it was not denied. In this section (Num 17:118:32), God's appointed leadership is confirmed and supported. At this juncture in the community's history, the priesthood exerted its legislative power to establish wages, inheritance, and indeed, prerogatives in worship for its membership.

Some scholars believe that the unit as a collection reflects the late postexilic activity of priestly expansion noted in Numbers 16-17 (Wellhausen 1885/1994:156-59; Olson 1996:8). Wellhausen argued that there were three historical stages in the development of tithe: first was a voluntary offering to God at the tribal sanctuary, which was consumed by the 
worshippers in a communal meal, which was not appropriated by the Levites or Priests (Amos 4:4); second, an annual obligation and the communal meal at the central sanctuary (Deut 14:22-27); and third, an annual obligation to the cities, collected by the Levites and no longer eaten by the worshippers (Num 18:21-28; Neh 10:37-39). So, Wellhausen concluded that Numbers 18 has the setting of post-exilic Judaism, which came much later than the other codes that provided for tithing.

Conversely, Kaufmann and McConville have argued that the Levitical tithe law of Numbers obviously belongs to a time when the Levites were still numerous and served a significant function. The custom of vowing tithes must have been widespread and served to maintain them. When the Levites afterward dwindled in numbers and importance, the tithe law of Numbers 18 became obsolete. Tithes were brought, instead, to the temples in preexilic times. But this obsolete law still remained on the priestly scrolls and was to play a decisive role later (Kaufmann 1972:190; McConville 1984:71). According to this view, it is not possible that the priestly authorities of post-exilic times bestowed this most lucrative of all sacred gifts upon lowly temple servants, the Levites. The fact is that the numerous priests of the postexilic times (according to the lists in Ezra 2:36ff and Neh 7:39ff, they number in the thousands) were unable to live on the heave offering and the sacrificial portions that were assigned to them by the Torah. The Levites especially became negligible when the many altars were done away with, and the entire priesthood had to share the sacrificial portions of the single postexilic altar. On the other hand, the Levites of the Restoration were few and powerless (Ezra 2:40ff; cf. 8:15ff). That the priests of those times should have created a tithe law which condemned them to penury, only to annul it in effect shortly afterward is, of course, an absurd assumption (Kaufmann 1972:190-191).

Moreover, Weinfeld (1971:1159-1161) has suggested that the tithe given to the Levites in Numbers 18 is related to the Levitical cities which were given to the Levites (Num 35:18 ) out of the land apportioned to the Israelites. He opined that the Levitical cities listed in Joshua 21 (cf. 1 Chron 6:39-66) reflect the Davidic period; that some of the cities were not occupied before David, and on the other hand, the geographic scope of the list could not be imagined in the post-Solomonic period. Royal granaries and warehouses were kept in the cities under the supervision of the Levites. Since the tithe, in its original form, was a tax associated with palace and the temple alike, it stood to reason that these cities, which were counted as temple cities (cf. Num 35:9ff), served as storages of the tithe. Apparently, Numbers 18 might fit well the period of the United Monarchy, but there is no evidence concerning the Levites and their cities after this period, and probably the priestly law on tithing was not implemented at all after the introduction of the Monarchy. The cult centralization and the abolition of tribal sanctuaries under Hezekiah and Josiah heralded a new paradigm shift in the concept and practice of tithing. Moreover, when they were no kings to serve as trustees of the granaries and warehouses during the exilic and postexilic era, the concept received further transformations (cf. Grintz 1971:957). The tithe system in Deuteronomy reflects more of the practice during the cult centralization period.

Evidence in support of a pre-exilic dating for Numbers 18 could be deduced from the study of Rooker (1988:45-52; 2000:1106) on the use of the Old Testament in the book of Ezekiel. In the study, Numbers 18:1-7, 22-23 was believed to be used by Ezekiel in Chapter 44:9-16 (on the prerogative of the priest over the Levites). And it was believed that Numbers 18 was an earlier Old Testament text. If the assumption is correct, then Numbers 18 is pre-exilic because most scholars believe that the book of Ezekiel is an exilic or a postexilic composition. 
The argument that Numbers 18 was literally composed or redacted by a priestly author sounds convincing, especially in establishing the responsibilities and wages of the priestly tribe, and the prerogatives of the Aaronic priesthood. The social setting should probably be when the activities of the Levites were still prominent and relevant. It is difficult to accept a post-exilic setting of the genre, because most scholars agree that during the postexilic era, the position and impact of the Levites had dwindled, and the priests were more in number and had taken over their functions. A pre-exilic setting of the genre seems more probable.

\section{Earlier Function}

The primary intention of the elements in our chosen pericope is legislative. Davies (2004:189) highlighted the three episodes that warranted Numbers 18. First was the account of the rebellion of Korah (Num 16:1-35), which appears to be designed to affirm the legitimacy of the Aaronic priesthood. The second involved a further unrest in the Israelite camp (Num 16:41-50), where Moses and Aaron were held responsible for the death of the Israelite leaders. The LORD was displeased by sending a plague, which only stopped after Aaron offered incense and made atonement for the people. The need for mediation for God's people was clearly evident as it was in the Sinai pericope (Ex 20:18-21). The final incident was the budding of Aaron's rod (Num 17:1-13). The intention was to get rid of rebellion against the choice of Aaronides priesthood (Num 17:5). The effect of the three episodes was to reinforce the understanding that discontent was widespread and deeply entrenched among the people; but the need for mediation was established and the priestly prerogatives of the Aaronides were vindicated.

We agree with Knierim and Coats $(2005: 220)$ that Numbers 18 established priestly authority and wages in relationship to their work in the sanctuary territory. Chapter 18:1-7 establishes the priestly duties of Levi/Aaron with recognition of a death threat in the process; vv 8-19 define wages for the priests; vv 20-24 define the inheritance for the Levites; and vv 25-32 establish the tithe of tithes to the priests.

\section{The Connection of Numbers 18 to the Priestly Tradition ${ }^{4}$ in Numbers and Pentateuch}

The context within which we shall discuss the connection of Numbers 18 to the priestly tradition in Numbers and Pentateuch will be presented in relation to: (1) the designation of duties and wages for Aaron and his sons; (2) the unique role of Levi as a tribe without land inheritance; (3) the fatal character of the holy place and the holy gifts; and (4) the tithe as a

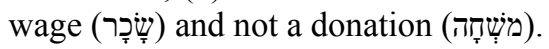

\section{The Designation of Duties and Wages for Aaron and his Sons}

As we have noted earlier, the three narrative episodes in Numbers 16-17 might have led to the composition of Numbers 18. The historical conflicts and rivalries among various priestly and Levitical groups in the actual life of ancient Israel and its cult may well lie behind some of these texts. They emphasized the community's obligation to support the Aaronic priests and Levites in their work of protecting the people and ministering in the sanctuary at the centre of the camp. The designation of duties and wages for Aaron and his

$4 \quad$ The priestly tradition in the Pentateuch places much emphasis on the activities of the cult and its personnel. 
sons has other parallels in the Pentateuch. Examples are Numbers $3: 10,38 ; 4: 1-20$; 6:2226; etc; Exodus 28:40-43; Leviticus 22; Deut 12:11-12; 14:28-29; 26:12.

The texts cited above show some evidence of having been shaped and edited over a considerable length of time and through various contexts in Israel's history. Several scholars have suggested that a priestly tradition has influenced the pericopes (see Olson 1996:117; Knierim \& Coats 2005:219; Brown 2002:151-157). We are indeed obliged to assume that a priestly writer or redactor, probably of Aaronic descent, designed the pieces to ensure unquestioning loyalty to and support for the dominance of the priestly line of Aaron. The references in Deuteronomy show some signs of priestly influence which are quite different from the others. There is no clear prominence for the house of Aaron in Deuteronomy. We shall elaborate on this later.

\section{The unique Role of Levi as a Tribe without Land Inheritance}

The unique role of Levi as a tribe without a territorial inheritance featured prominently in the book of Numbers. The Levites were expressly excluded from the general census (1:47-54; 2:33); but were counted separately (3-4). They were in charge of the Tabernacle and its furnishings, carrying them from place to place (Num 2-3) They camped around the Tabernacle; performed guard duty (Num 1:53; 8:23-28); underwent purificatory rites when they joined the work force (8:5-22); marched before the tribal units laden with the dissembled Tabernacle $(10: 17,21)$. The special calling of the priests and Levites in Numbers 18 included having no tribal territory of their own in the land of Canaan (18:24), for which they were rewarded with the tithe (18:21-24; Olson 1996:117; Milgrom 1989:xl). They were assigned to assist Aaron and his sons, not as priests but as cultic servants, especially in the duty of guarding the sanctuary against encroachers. They were identified by this function, hence the name 'Guardians of the Tabernacle of the Lord' $(31: 30,47)$. Forty eight cities were assigned to them in the future Promised Land, six of which were designated as asylums for those who commit unintentional homicide (35:6, 9-15).

In Leviticus 27:30-33 there is a declaration that a tenth part of both seed from the ground and fruit from the tree, herd and flock are holy to the Lord. And in Numbers 18:21, 24 , it is declared that the LORD had given to the Levites as their portion the tithe of the Israelites, which they set apart as an offering to the LORD. The cultic understanding of the two passages is obvious. The LORD is the owner of the tithes, and it is the LORD who has assigned the same to the Levites as their wages for the service they render to the LORD in the Tent of Meeting. This meticulous attention to cultic duties and rewards clearly portrays the work of a priestly writer.

\section{The fatal Character of the Holy Place and the Holy Gifts}

The priestly tradition did not only present the duties and rewards of the cultic services, but also, the fatal nature of the holy place and the holy gifts. Legislation on the fatal character of the holy place and the holy gifts featured prominently in Numbers 18:

The LORD said to Aaron: You and your sons and your ancestral house with you shall bear responsibility for offences connected with the sanctuary, while you and your sons alone shall bear responsibility for offences connected with the priesthood (Num 18:1).

You shall not bear sin for it, since you have set apart from it the finest of it; and you shall not profane the holy things of the children of Israel, lest you die (Num 18:32). 
The above passage comes naturally after the preceding one (i.e. Ch 16-17 on rebellion and judgement) and gives the answer to the people's question in 17:13, "Are we all to perish?" Aaron, his sons, and the Levites were to bear the consequences for any cultic impropriety (cf. Exd 28:38). All Levites were responsible for the sanctuary; only Aaron's sons were responsible for priesthood, because they ministered at the altar and guarded the purity of the sanctuary. Ashley (1993:340-341) reports that the necessity of guard duty for the tabernacle was restated here in the light of Korah's rebellion and the panic that ensued after the plague. The penalty for failure to stop encroachment on the sacred vessels and the altar is death at the hand of God. This penalty might seem strange since the punishment for offences that have a disastrous effect on society is usually death by human agency.

Also, the Levites were cautioned against tampering with the tithe of tithes. How they managed the tithes determined what happened to them. According to Milgrom (1997:157), "Unauthorized contact with sancta is penalized with a monetary reparation, for example, if sacred food is accidentally eaten (Lev 22:14-16), or with capital punishment, if the act was performed deliberately" (cf. Lev 10:1-2; Num 16). What was presented to the LORD was to be regarded as holy ( $\mathrm{vv} 8,32$ ), and most holy ( $\mathrm{vv} 9,10)$; those who ate such food must regard it as something most holy and be ceremonially clean (vv 10,13) as they ate it. It put greater demand on the recipients of the gifts than on their givers. Holy gifts needed to be matched by holy recipients. In Levine's view, the sense of Numbers 18:32 was that the Levite could avoid punishment for defiling the sacred donations of the Israelites by properly contributing to the priests one tenth of the tithes they collected (Levine 1993:453). The death of the two sons of Aaron, Nadab and Abihu, and the judgement on Korah and the 250 men who offered incense, serve to warn about the fatal nature of the cultic involvements.

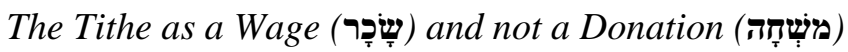

To compensate for the fatal nature of guarding the holy place, and for not having a territorial inheritance in the Promised Land, the Levites were to receive every tithe in Israel of what was earned or produced in the land. Milgrom (1997:155) reported that the tithe was a compulsory, permanent grant to the Levites; its cultic provisions reflected a system of

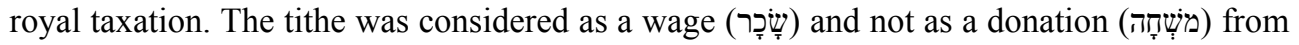
the Israelites, in compensation or return (חלֶ) for the life threatening duties of the Levites at the Sanctuary (v.31). Apparently, the Israelites were paying for the services rendered to them, or on their behalf, by the Priests and Levites.

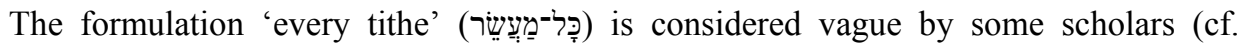
Levine 1993:451; Ashley 1993:354). The contention is that it raises doubt whether it included both the tithe from agricultural produce and the increments of herds and flocks, as stipulated in Lev 27:30-33. The contention here is not necessary since Numbers 18 did not mention the goods subject to tithing as it is found in Leviticus or other codes that provided for tithing. Most likely, the author took it for granted that the audience understood what was being taught them about the wages for the priesthood and the Levites. The phrase, 'every tithe' may mean nothing more than every one that was offered, whatever its kind. Rather than an inheritance of land in the midst of the children of Israel in Canaan, the Levites' inheritance is the tithe (21a, 24a).

Just as other Israelites were expected to set aside a contribution to the LORD from the abundance of their inheritance in the land of Canaan, so the Levites were to set aside such a contribution from their inheritance, which was the tithe. This contribution would be 
counted to them as the Levites' equivalent to the Israelites' contribution from their earned or produced inheritance. Numbers 18 speaks of the function of the Levites as complementary to that of the priests. Though the Levites were vital to Israel's survival since they were to act as those who would save the people from extermination, they were still not to be confused with the priests. Since the LORD had granted the people's tithe to the Levites, the Levites' tithe would go to the priests.

Contrary to the view of some scholars, the tithe in Numbers is not voluntary but obligatory. The use of the word 'wage' or 'payment' (שָָָָָ) means that the tithe does not take the form of a charity in Numbers. The case in Deuteronomy 14:22-29, in which the tithe is indeed a charity, follows a different sociological motivation. Milgrom (1990:433) identified another verb (תחקחו), ${ }^{5}$ which means to 'take by force', implying that the Levites were not dependent on the whims of the landowner. The verb can also mean 'take possession', 'seize', 'withhold'. This implies that the tithe was not a philanthropic gesture of the payer, but a duty he/she must perform. Moreover, the tithe speech from the LORD to Aaron and Moses for the people was not a request but a command (vv 8, 21, 24).

\section{The Use or Interpretation by other Biblical Traditions}

Numbers 18 clearly stated that every tithe in Israel should be given to the Levites in return for their service which they serve in the Tent of Meeting (vv 21, 24). But in Deuteronomy the stipulation is quite different. The recipients included the payer of the tithe in a communal meal, the Levite, the foreigner, the orphan and the widow (Deut 14:22-29). And this has raised a number of questions. So, the nature and the scope of tithing in the book of Deuteronomy is not the focus of this article.

In 1 Samuel 8:15, 17, Samuel warned the Israelites that the request for a king would mean the rejection of the kingship of the LORD. The king would enforce his will upon them, requiring from them a tenth of their field produce and of their flocks. This comment had a basis in a general custom among the nations of the ancient times. In light of the standard procedure of kings to take a tenth, one could argue that at least part of the underlying rationale of the Levitical tithe was the recognition of the LORD'S theocratic kingship in Israel. The tithe was the means by which God's palace (the tabernacle/temple sanctuary) and courtiers (the Levites and priests) were supported by the people over whom God ruled. In essence, the tithe was the LORD'S tax as the theocratic king of Israel. Thus, it seems likely that the theology of the obligatory Levitical tithe in Numbers 18 was to some degree based on the underlying logic of the obligatory taxes of a king as found in the Ancient Near East (cf. Averbeck 1997:1038; Weinfeld 1971:1158).

The stipulations of Numbers 18 are clearly implied in Nehemiah 12:44-47. The portions required by the law for the temple staff were differentiated as contributions, the first fruits, and the tithes. In the days of Zerubabel and of Nehemiah the Israelites gave the obligatory portions for the singers and the doorkeepers as each day required; and they set apart the portion for the Levites, and the Levites in turn set apart the portion for the Aaronides. As long as Nehemiah was around, the stipulation for tithing was enforced (Neh 13:6-15). We agree with Verhoef (1974:121) that the period between Nehemiah's first visit and second visit to Palestine is presumably the historical background of Malachi's complaint that the people were robbing God, because they neglected the compulsory contributions, consisting

(Verb, qal, imperfect, second person, masculine, plural). This position is supported by the LXX translation $\lambda \dot{\alpha} \beta \eta \tau \varepsilon$ (take in the hand, take hold of, grasp), which has a connotation of a tax collection. The tithe was not supposed to be a philanthropic gesture of the payer, but an obligation. 
of tithes and other offerings (Mal 3:8-10). That the tithes were stored in the storehouse of the temple may be learned from Malachi 3:10; Nehemiah 10:38, 39; 12:44; 13:5, 12, 13; 2 Chronicles 31:4ff. The same sources provide information about the custodians of these stores and about the way in which the tithes were distributed among the temple personnel (e.g. Neh 13:13). Whereas, in Numbers 18, the tithes could not possibly be brought until Israel had become a settled agricultural community, Malachi, Nehemiah and Chronicles give us an idea of the actual practice of tithing in the Old Testament. According to Averbeck (1997:1044):

Although it seems that the Israelites often neglected the tithe laws (e.g. 2 Chron 31; Neh 13:10; Mal 3:8-10), this does not mean that the laws themselves were impractical or utopian. Properly understood, these tithe regulations could have been a workable and economically reasonable means of providing for the priests, Levites, and tabernacle/temple worship system in either the pre- or postexilic periods of Old Testament history.

\section{Relevance to Africa}

The influencing factors for the adoption of the tithe system in Numbers 18 were obvious, and they could be of great relevance to the church in Africa. They included: theological, moral, economic, political and socio-cultural factors. Theologically, the payment of tithes was founded in the belief that God is the maker of the heavens and the earth, and the sovereign owner and controller of its affairs. This understanding should control the stewardship efforts of the churches. Tithing represents the confession that everything which we have belongs to the Lord, and that we are obliged to dedicate it to the honour of His name. Morally, the tithe in Numbers 18 was portrayed as a right and not as a privilege. It was legally binding that labourers deserved their wages; and not as a privilege because they duly merited it by their labour. This understanding was true in the New Testament times centuries later when Apostle Paul said:

Don't you know that those who serve in the temple eat food from the temple, and those who serve at the altar receive a part of the offerings? In the same way the Lord commanded those who proclaim the gospel to receive their living by the gospel (1 Cor. 9:13-15).

The tithe system is a call to believers to serve their God at a significant cost to themselves, and not at the expense of others. Economically, tithing would generate enough local resources for ministry which was the case in Numbers 18 . When the church is economically strong, it can be politically independent. For socio-cultural implications, later biblical traditions similar to Numbers 18 confirm that negligence of this practice would have serious consequences on the communal principle, which it was meant to impact. The tithe system is a valuable lesson for the Church in Africa, not as an imposition of a Jewish custom but as a guide in Christian stewardship. The principle at stake in the tithe system is the principle of percentage giving.

\section{Conclusion}

The study of Numbers 18 has shown that the background tradition history of the priestly emolument centres on the activity of the sanctuary and the priesthood. The primary intention of the pericope is legislative. The Israelites were to tithe as a means of expressing worship to the LORD and obedience to the laws. Numbers 18 established priestly authority and wages in relationship to their work in the sanctuary territory. Verses 1-7 established the priestly duties of Levi/Aaron with recognition of a death threat in the process; vv 8-19 defined wages for the 
priests; vv 20-24 defined the inheritance for the Levites; and vv 25-32 established the tithe of tithes to the priests.

The practice of tithing in Numbers 18 did not depict exactly the practice in other ancient Near Eastern societies. The social setting of Numbers 18 probably was pre-exilic, when the activities of the Levites were still prominent and relevant and not a post-exilic setting, when the impact of the Levites had dwindled and the priests were more in number and had taken over their functions. The priestly tradition of Numbers did not only present the duties and rewards of the cultic services, but also, the fatal nature of the holy place and the holy gifts. They were warnings against the encroachment on the sanctuary and the altar, or the abuse of holy gifts.

There were theological, moral, economic, political, and socio-cultural factors which affected the priestly emolument in Numbers 18 . The theological understanding that the LORD was the owner of the land and the Israelites were to tithe all the wealth of the land as a means of submitting to that sovereignty forms the position of this paper. A good understanding of the priestly emolument in Numbers 18 can motivate a more reflective theological-ethical application of stewardship amongst believing communities in Africa.

\section{BIBLIOGRAPHY}

Ashley, TR 1993. The Book of Numbers. (NICOT), Grand Rapids: Eerdmans.

Averbeck, RE 1997. sv מעשר. NIDOTTE 2, 1035-1055.

Brown, R 2002. The message of Numbers: Journey to the Promised Land. Leicester: Intervarsity.

Carpenter, EE 1988. sv 'Tithe'. ISBE 4, 861-864.

Dahood, MJ 2003. sv 'Ugarit'. NCE 14, 266-267.

Gnuse, R 1999. sv 'Tradition History'. DBI 2, 583-588.

Grintz, YM 1971. sv 'Temple'. EJ 15, 942-959.

Harrison, RK 1992. Numbers: An Exegetical Commentary. Grand Rapids: Baker.

Jagersma, H 1981. 'The tithes in the Old Testament,' in Albrektson, B, et al (eds.), Remembering all the way: A collection of Old Testament studies published. Leiden: Brill, 116-128.

Kaufmann, Y 1972. The Religion of Israel: From its beginnings to the Babylonian exile. New York: Schocken Books

Knierim, R F and Coats, GW 2005. Numbers (The forms of the Old Testament Literature, 4). Grand Rapids: Eerdmans.

Levine, BA 1993. Numbers 1-20. (AB), New York: Doubleday.

Lichtheim, M 2002. sv 'Famine stella'. COS III, 130-134.

McConville, JG 1984. Law and theology in Deuteronomy. Sheffield: JSOT.

Milgrom, J 1990. Numbers (JPS Commentary, vol 4). Philadelphia: Jewish Publication Society of America.

Olmo Lete, GD 1999. Canaanite Religion according to the Liturgical Texts of Ugarit. Bethesda: CDL. 
Olson, DT 2003. sv 'Book of Numbers'. Dictionary of the Old Testament Pentateuch, 611-618.

Pardee, D \& Yon, M 1992. sv 'Ugarit'. ABD 6, 695-720.

Verhoef, P A 1974. 'Tithing - a hermeneutical consideration', in Skilton, JH (ed.) 1974. Law and the prophets, 115-127. [si]: Presbyterian and Reformed publishing Company.

Weinfeld, M 1964. 'Cult Centralization in Israel in the light of a Neo Babylonian Analogy.' JNES 23, 202-212.

Weinfeld, M 1971. sv 'Tithes'. EJ 15, 1155-1163.

Wellhausen, J 1994 (1885). The Prolegomena to the History of Israel. Chico: Scholars. 